\title{
Predictors of Emotional Intelligence among Academic Staff in Selected Universities in Nairobi County, Kenya
}

\author{
Maria Ntarangwe, Stephen Asatsa (PhD), Elijah Macharia Ndung'u (PhD) \\ Department of Psychology, The Catholic University of Eastern Africa, Kenya
}

\begin{abstract}
The academic staff in the university is a vital component in enhancement of academic affairs in any university. Due to the unending changes and dynamics that increase pressure and work related stress that academic staffs are subjected to, they are required to develop high levels of adaptability in their careers to enhance creativity so that they remain relevant. The study was based on Emotional intelligence theory and Career construction theory. A descriptive survey research design was used for this study. The target population was 403 academic staffs from selected universities in Nairobi County, Kenya. The total sample size was 201 respondents selected using two stage cluster sampling. Data was collected using Emotional Intelligence Scale EI (PcSc) scale developed by Mehta \& Singh (2013). To establish internal consistency of the instrument, reliability was determined and Cronbach's alpha coefficient was 0.824 . Descriptive statistics were applied to analyze quantitative data using SPSS. The study had several findings: High means in indicators of emotional intelligence were recorded where the highest score was in self- awareness (Mean = $4.13 \pm .53)$. This was followed by self- motivation (Mean $=3.85 \pm$ $.53)$, social skill was rated the third aspect of emotional intelligence $($ Mean $=3.83 \pm .43$ ) and the lowest was emotional regulation $($ Mean $=3.68 \pm .55)$. The findings also indicated that there were differences in the mean score of Emotional intelligence across age, gender, education level, type of university and teaching experience. However the analysis of variance showed no significant differences in emotional intelligence in terms of age and gender. Moreover, only the mean of social skills had a significant difference in terms of level of education, experience and type of university. The major recommendation therefore given by the research was enhancement of selfawareness, self- motivation, emotional regulation and social skills strategies both by individuals and various organizations in order to improve job outcomes. This would be through trainings, guidance and counselling and team building. The researcher anticipated that the results from the study will facilitate the formation of an academic staff that are holistically intelligent.
\end{abstract}

Key Words: Emotional Intelligence, Academic Staff, SelfAwareness, Emotional Regulation

\section{BACKGROUND}

$\mathrm{T}$ he academic staffs in the universities are required to work in line with the societal expectations. According to Maasen, Andreadakis, Gulbrandsen and Stensaker, (2019), the society today, highly demands that universities should not only produce new knowledge, but also take the responsibility for transferring relevant knowledge to society and engaging with society. Relevance in this case may be viewed from different perspectives. In its own nature, the society is dynamic and much is happening around us as human beings. In both the developed and developing countries, transformations are happening.

As of 2020, there is an increasing body of literature surrounding adaptability since employers are developing interest with an employee's ability to deal with change and uncertainty unlike in the past where intellectual intelligence and other skills were given attention,. The question of how to increase adaptability so as to meet all these demands remain a puzzle. Adaptability being a soft skill and not formally trained would therefore need to be placed along variables that will enhance it. The research sought to assess whether emotional intelligence has a relationship with adaptability.

Emotional intelligence has gained a lot of attention due to importance that it has generally picked in work places. Goleman (2003) provided one of its earliest definitions that are influential and well-known. In his model that gained rapt attention, he included five characteristics of emotional intelligence that include: self-awareness, self-regulation, motivation, empathy and social skills (Goleman, 1998).

Al-Hamami1, Hashim, Songip and Al-Saeed (2015) suggested that EI is even more important than intellectual intelligence and technical skills in as far as accomplishing tasks in an organization are concerned. In 1995 Daniel Goleman used EI as an alternative construct to intelligence quotient to predict employees' aspects line performance and motivation among others (Goleman, 1995)

EI is a key element in the success of any given institution. Research has found out that there is a strong relationship between emotional intelligence and job factors. However, research has shown that EI plays a key role in making the people in various careers successful, (AlHamami1, Hashim, Songip and Al-Saeed, 2015). They further note that EI is the most vital element in performing tasks at work as well as achieving organization's success. To gauge the EI of a person, different theorists have proposed different constructs. This research shall focus on the constructs proposed by Goleman, (1998). One of the key indicators of emotional intelligence that he proposes is of self- awareness. 
Self-awareness as defined broadly by Gu, Strauss, Bond, \& Cavanagh, (2015) is the description of the extent to which someone is fully aware of their inner states and how they interact with others. An employee therefore should be self -aware since it impacts much on what they do. Feldman, Dunn, Stemke, Bell, \& Greeson, (2014) proposed that it is self-awareness that does not only stop at well-being and mental health but goes even further to influence the day-today functioning of an individual. If an employee has high levels of self- awareness, it also combines to factors that amount to high levels of emotional intelligence

Emotional regulation is another key construct of emotional intelligence. Emotion regulation, gives prominence to the processes that allow people to have influence over emotions they are experience; the type of emotions, the moment they experience those emotions; the time the emotion begins and the duration it takes, as well as and the various ways they experience those emotions and express them (Pena-Sarrionandia, Mikolajczak, \& Gross, 2015).

When an academic staff has high EI they are able to regulate their emotions successfully and they do this when most needed with flexibility that allows other hidden emotions to be visible. Gross and Jazaieri, (2014) noted that emotional regulation can be experienced both intrinsically where one regulates their own or extrinsically where a person is able to manage another person's emotions. If a head of department for instance wants to make the lectures work overtime and he raises his anger for their underworking, the emotional regulation strategy will be considered successful if the lecturers get to work overtime.

Noorbakhsh, Besharata, and Zarei, (2012) opine that an emotion-regulation strategy is considered adaptive or maladaptive, based on the emotion itself, its intensity, as well as context in which the emotion regulation strategy was employed. This is what helps the person therefore to know which emotion should be regulated and the person therefore determines ways of regulating that particular emotion. Gross and Jazaieri, (2014) suggested that emotion-regulation strategies specify the criteria that a person can put in place to reach the goals to an end of their choice. The importance of emotional regulation cannot be under estimated. This is the reason why Pena-Sarrionandia, Mikolajczak, \& Gross, (2015) suggested that emotional regulation is a very crucial construct when it comes to defining the EI of a person.

The levels of EI of academic staff can hardly be defined without considering the self- motivation of a person. Motivation has numerous and diverse definitions. The definitions vary. One of the definitions view motivation from a psychological perspective that comprise the energy (Eymur \& Geban, 2011). This energy can be considered in this context as the drive to teach. Naz, Shah, \& Qayum, (2020) define motivation as the sum of cognitive perspective, biological and social perspective when it focuses on the behavior of a person. Iksan, (2012) considered motivation either Intrinsic when it relates to the inner force of behavior, such as an inner desire or extrinsic when it arises from external factors like family expectations and pressures, or even circumstances at workplace including demands and responsibilities. Naz, Shah, \& Qayum, (2020) opine that both forms of extrinsic and intrinsic motivation are overlapping and more often than not they depend on each other.

Besides personal competencies, emotional intelligence also gives social competencies attention since a person does not live in isolation and therefore being a social being, their social skills are key constructs of emotional intelligence. Goleman, (2000) defined Social skills as means or a way of directing human relations or social skills through the process of managing and at the same time adapting to the emotions of other people. He therefore considered these social skills as strong positive influence that a person possesses in the effort of managing the emotions of other people and treating them in a decent manner. An academic staff has so many people he needs to relate with including students, other members of staff, administration, parents amongst others. Kumar \& Devi (2016) view Social skills as discrete, observable, and teachable behavior that helps the individual in society that initiate and sustain social interaction and that are decently associated to measures of social competence. These social competences are therefore the ones used as constructs of emotional intelligence.

\section{Statement of the Problem}

Academic staff in universities are constantly faced with sudden changes in policies and culture, impending pandemics, transitions at work, struggles to maintain worklife balance, increased expectations from universities and the commission of university education, increased exposure to online content, digitalization in teaching and other increased dynamics. For instance, in the recent COVID-19 pandemic that hit the world over, many people including the academic staff across universities have had difficulties in smoothly adapting to the transition from onsite to working online. Some staff members end up performing below expectation, neglecting social life, being stressed, angry, and others depressed by their jobs.

Besides technical skills and intellectual intelligence that can help an academic staff adapt to these dynamics, emotional intelligence is a factor that that would be important to help the staff have better results in the various job factors. This type of intelligence is however not acquired through direct teaching but rather it is developed. The researcher therefore sought to establish the predictors of emotional intelligence among the academic staff in selected universities in Nairobi County, Kenya.

\section{Research Objective}

The study purposed to establish the demographic predictors of emotional intelligence among the academic staff in selected universities in Nairobi County, Kenya 


\section{METHODOLOGY}

This study employed a descriptive survey design. According to Orodho (2009), a descriptive survey refers to a data collection method that collects data from the sampled population through the use of questionnaires and interviews. This study aimed at collecting data with regard to individuals' opinion, attitudes, behaviours and habits, hence descriptive survey research design was appropriate. When asking participants about their views, opinions and behaviours, the participants give a self- report which in turn would require collection of quantifiable information (Mugenda, 2003). This design was deemed fit for this study because the study's main aim was to gather information from various participants with regard to how EI impacts an individual's CA.

The goal of descriptive research according to Nassaji, (2015) is to describe a phenomenon and its characteristics. This study sought to investigate predictors of emotional intelligence among the academic staff in selected universities in Nairobi County, Kenya. In order to obtain this information, survey tools, precisely questionnaires were used to gather data. Data was collected using Emotional Intelligence Scale EI $(\mathrm{PcSc})$ scale developed by Mehta \& Singh (2013) that was distributed to 201 participants who had been sampled using a two-stage cluster sampling method. The data was collected in three universities and analyzed quantitatively, using frequencies, percentages, averages, means and standard deviation so as to determine the extent to which the predictors influenced emotional intelligence. A bivariate analysis was run to determine if there were any differences in the learners' responses based on their age, gender, level of experience, academic achievement and type of university that they were teaching.

\section{The Study Area}

The study was conducted in universities in Nairobi County. Nairobi is the capital city of Kenya and one of Africa's key financial, business, transport, communications, nongovernmental organization, and diplomatic capitals. Nairobi City County consists of 17 Sub counties and 85 wards. It borders Machakos County, Kiambu County and Kajiado County, and covers an area of 696 square kilometers. From the 2019 population census, the County population is estimated at 4,397,073. The research will be done in private and public universities in Nairobi County.

Nairobi County was selected due to the fact that being the capital city of Kenya, it has a variety of universities as well as a mixed population of people coming from different parts of the world. Universities that are in Nairobi which is the city's capital implies more pressure for the employees to meet their cost of living and hence most of them find themselves teaching in more than one university due to the proximity and accessibility from one university to another.

\section{Study Population}

According to CUE, (2019), the total number of universities in Kenya stands at 71 . The 71 Higher institutions of learning constitutes of 37 private and 34 public universities. However in Nairobi County, only 8 private universities and 3 public universities were chattered (CUE 2019).

\section{Sampling Procedures and Sample Size}

Sampling procedure refer to the process of selecting a number of individuals for a study in order to ensure that the individuals selected represent the large group from which they were selected (Kamau, Githi \& Njau, 2014). A two stage cluster sampling was utilized. The researcher randomly selected the universities which were considered as the clusters. According to Mugenda (2009) a sample size of between 10 and $30 \%$ is a good representation of the target population and hence the researcher assumes that proposing the maximum limit of $30 \%$ in this study was adequate for selecting the universities to be considered.. Names of the universities were written on pieces of paper and 1 public and 2 private universities were selected. The target population from the three universities selected was 403 (University Human resource managers, 2021). From each university, the researcher identified the faculties and departments as clusters. Simple random sampling was used to pick respondents from each of these clusters.

To determine the sample size for the first phase of the research, Taro Yamane (Yamane, 1973) formula with 95\% confidence level will be utilized. The calculation formula of Taro Yamane is presented as:

$$
\begin{aligned}
& \mathbf{n}=\mathrm{N} / 1+\mathrm{N}(\mathrm{e})^{2} \text { Where }: \\
& \mathrm{n}=\text { sample size required } \\
& \mathrm{N}=\text { number of people in the population } \\
& \mathrm{e}=\text { allowable error }(\%) \\
& \mathrm{n}=403 / 1+403 \times 0.0025=\mathbf{2 0 1}
\end{aligned}
$$

\section{Data Collection Instruments}

To measure EI, the researcher used the EI Scale EI ( $\mathrm{PcSc})$ scale developed by Mehta \& Singh (2013). The EI (PcSc) scale is a self-report questionnaire comprising two parts: personal competence and social competence that measures six facets of $\mathrm{EI}$ in the workplace. The $\mathrm{EI}(\mathrm{PcSc})$ scale employs a 5-point Likert scale with the following anchors: (1)extremely low competence (2), low competence (3), not sure (4), high competence(5),extremely high competence. The coding is reversed in certain items.

\section{RESULTS}

The study tested the role of various demographic factors on the EI of academic staff namely, age, gender, education level, years of teaching experience and type of university. The overall scores were obtained by averaging the total score for 4 items and obtaining the means. Scores ranging from 1 to 5 were categorize as follow: less than 2.5 indicated low 
competence and more than 2.5 indicated high competence on the EI subscales.

\section{The Role of Age in Emotional intelligence}

The study sought to examine the way in which EI varies across the age of the participants. The researcher categorized the participants with an age difference of ten years since the researcher considered a decade sufficient time to show differences in emotional intelligence if any. The research further discussed the trends that were observed in the various scales of emotional intelligence with relation to the age of the participant. Table one shows the differences in emotional intelligence in terms of age.

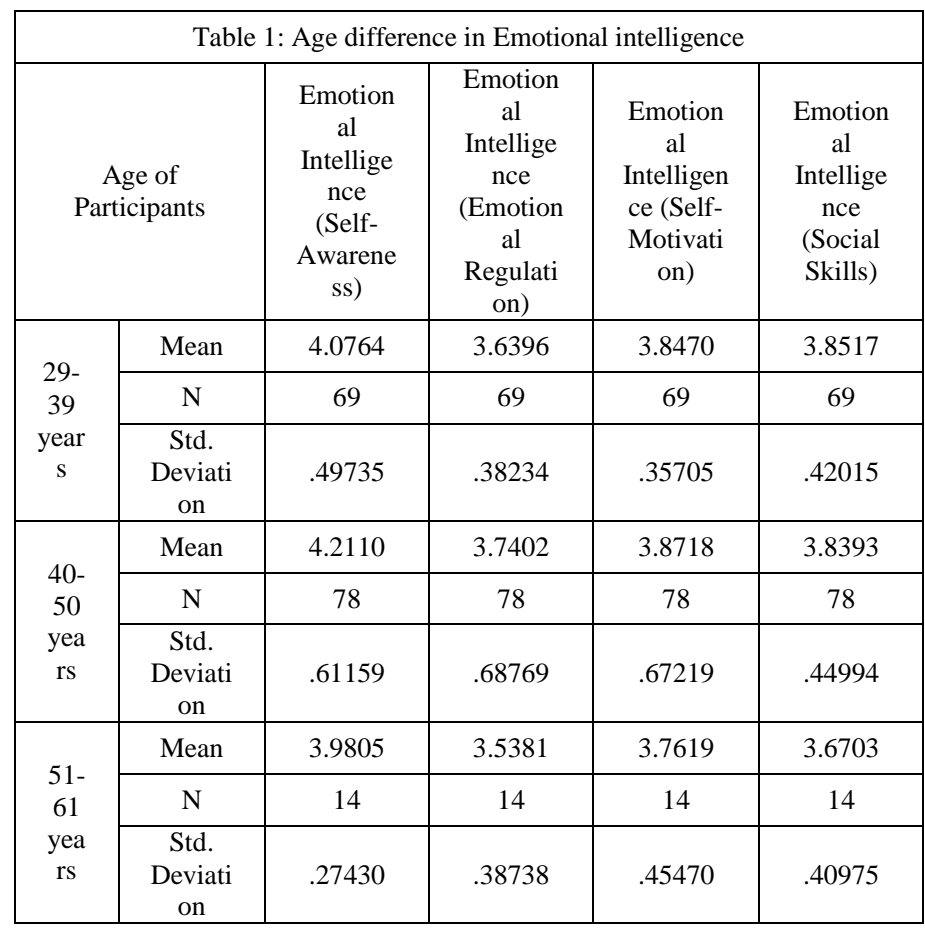

The study recorded the highest level of selfawareness at the age of 62-72 (Mean = 4.18) where individuals seemingly were concerned about their feelings and were aware of their strength, weaknesses, values, goals and decision making strategies. The lowest scores were recorded at age 29-39 (Mean $=4.08$ ). Similarly at the age of 62-72 there were high levels of emotional regulation (Mean = 3.93) and self -motivation (Mean= 3.89). Employees at this age bracket were in charge of their emotions and were motivated at work. However, age 62-72 and 18-29 were considered as outliers due to the scarcity of participants. The employees at the age bracket of 51-61 years recorded low levels of emotional regulation. (Mean $=3.54$ ) as well as selfmotivation $($ Mean $=3.76$ ). The youngest age group 18-29 recorded highest scores $($ Mean $=3.87$ ) when it came to social skills while the oldest recorded low competencies in social skills $($ Mean $=3.62$ ) The outstanding trends observed in emotional intelligence across the age of participants are discussed under Figure 1

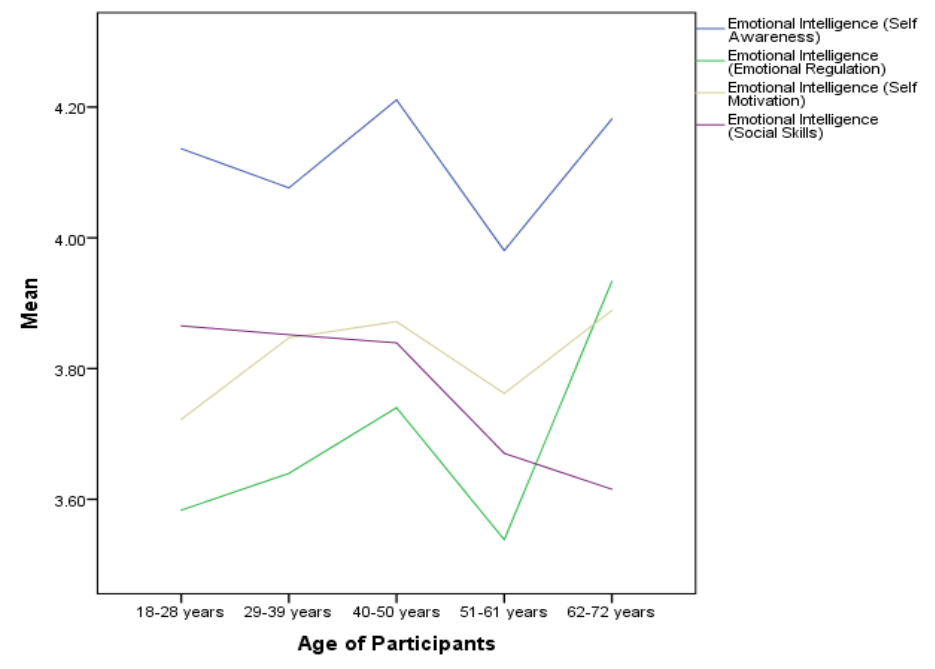

Figure 1

The findings clearly indicated that self- awareness reduced as the participants advanced in early years of adulthood ranging from age 18-39. The mean of participant $18-28$ years old $($ Mean $=4.14)$ increased to Mean $=4.08(29$ 39 years). This is the time when people get busy with building career and family and may therefore not focus much on themselves. However, the more the academic staff got into their mid- life the more they gave attention to their emotions and how those emotions influenced their careers. The mean score for self -awareness at ages 40-50, increased to (Mean = 4.21). At age 51-61 however, the least mean experienced in terms of self-awareness as the age advances where people seem to settle at the work place and homes and hence think less about their emotions. However, when at the retirement age of 62-72 (Mean $=4.18$ ), the staff start thinking and get concerned about how they feel and how this affects them and their work.

Similarly, emotional regulation increased from a mean of 3.58 (18- 28 years) to 3.63 (29-39 years), to 3.74 at age 40-50. However, the emotional regulation in academic staff reduced to $($ Mean $=3.54)$ at ages 51-61. Like in other constructs again at age 62-72 the levels of regulation that academic staff possessed over their emotions increased to Mean $=3.93$.

Self - motivation had a similar trend with an increase between year 18-28 $($ Mean $=3.82)$ to 29-39 years $($ Mean $=$ $3.85)$ to the age group between $40-50$ years $($ Mean $=3.87)$. The participants between age 51-61 had lowest mean $=3.76$ but in the subsequent years that neared the retirement years the level of motivation increased to Mean $=3.89$.

Social skills for participant had a different trend where the mean increased with decrease in age. Those with $18-28$ years recorded the highest means $($ Mean $=3.87)$. The means went reducing progressively to participant at age 29-39 $($ Mean $=3.85), 40-50($ mean $=3.84)$, 51- $61($ Mean= 3.67). The mean for social skills was lowest for age 62-72 (Mean = 3.62). This implied that the younger they were the more they were able to work in teams, build relationships, discuss, debate well and relate to someone who is even not known to 
them. Analysis of variance was further done to establish whether the differences in means were significant.

Table 2: One-Way Analysis of Variance of Emotional Intelligence by Age

\begin{tabular}{|c|c|c|c|c|c|c|}
\hline & & $\begin{array}{l}\text { Sum of } \\
\text { Squares }\end{array}$ & df & $\begin{array}{l}\text { Mean } \\
\text { Square }\end{array}$ & $\mathrm{F}$ & Sig. \\
\hline \multirow{3}{*}{$\begin{array}{l}\text { Emotional } \\
\text { Intelligence } \\
\text { (Self } \\
\text { Awareness) }\end{array}$} & $\begin{array}{c}\text { Between } \\
\text { Groups }\end{array}$ & 1.023 & 4 & .256 & .876 & .479 \\
\hline & $\begin{array}{l}\text { Within } \\
\text { Groups }\end{array}$ & 46.972 & 161 & .292 & & \\
\hline & Total & 47.995 & 165 & & & \\
\hline \multirow{3}{*}{$\begin{array}{l}\text { Emotional } \\
\text { Intelligence } \\
\text { (Emotional } \\
\text { Regulation) }\end{array}$} & $\begin{array}{c}\text { Between } \\
\text { Groups }\end{array}$ & .778 & 4 & .195 & .640 & .635 \\
\hline & $\begin{array}{l}\text { Within } \\
\text { Groups }\end{array}$ & 48.931 & 161 & .304 & & \\
\hline & Total & 49.709 & 165 & & & \\
\hline \multirow{3}{*}{$\begin{array}{l}\text { Emotional } \\
\text { Intelligence } \\
\quad \text { (Self- } \\
\text { Motivation) }\end{array}$} & $\begin{array}{c}\text { Between } \\
\text { Groups }\end{array}$ & .213 & 4 & .053 & .185 & .946 \\
\hline & $\begin{array}{l}\text { Within } \\
\text { Groups }\end{array}$ & 46.260 & 161 & .287 & & \\
\hline & Total & 46.473 & 165 & & & \\
\hline \multirow{3}{*}{$\begin{array}{l}\text { Emotional } \\
\text { Intelligence } \\
\text { (Social } \\
\text { Skills) }\end{array}$} & $\begin{array}{c}\text { Between } \\
\text { Groups }\end{array}$ & .447 & 4 & .112 & .599 & .664 \\
\hline & $\begin{array}{c}\text { Within } \\
\text { Groups } \\
\end{array}$ & 30.039 & 161 & .187 & & \\
\hline & Total & 30.486 & 165 & & & \\
\hline
\end{tabular}

There were mean differences noted in the bivariate analysis in the various construct of EI and age of participant. However the analysis of variance showed no significant differences in all the four indicators of emotional intelligence as indicated in table. The various $\mathrm{F}$ values that indicate these non-significant differences include. Self-awareness $(\mathrm{F}(4,161)=0.876 ; \mathrm{p}>$ $0.05)$ emotional regulation, $(\mathrm{F}(4,161)=0.635 ; \mathrm{p}>0.05)$ self-motivation, $(\mathrm{F}(4,161)=0.185 ; \mathrm{p}>0.05)$ social skills ( $\mathrm{F}(4,161)=0.599 ; \mathrm{p}>0.05)$.

\section{The Role of Gender in Emotional intelligence}

The study sought to examine the way in which emotional intelligence varied across the gender of the participants.

\begin{tabular}{|c|c|c|c|c|c|}
\hline \multicolumn{6}{|c|}{ Table 3: Gender differences in Emotional intelligence } \\
$\begin{array}{c}\text { Gender of } \\
\text { Participants }\end{array}$ & $\begin{array}{c}\text { Emotion } \\
\text { al } \\
\text { Intellige } \\
\text { nce (Self } \\
\text { Awarene } \\
\text { ss) }\end{array}$ & $\begin{array}{c}\text { Emotion } \\
\text { al } \\
\text { Intellige } \\
\text { nce } \\
\text { (Emotio } \\
\text { nal } \\
\text { Regulati } \\
\text { on) }\end{array}$ & $\begin{array}{c}\text { Emotion } \\
\text { al } \\
\text { Intellige } \\
\text { nce } \\
\text { (Self- } \\
\text { Motivati } \\
\text { on) }\end{array}$ & $\begin{array}{c}\text { Emotion } \\
\text { al } \\
\text { Intellige } \\
\text { nce } \\
\text { (Social } \\
\text { Skills) }\end{array}$ \\
\hline \multirow{4}{*}{ Male } & Mean & 4.1186 & 3.6341 & 3.8184 & 3.7946 \\
\cline { 2 - 6 } & N & 82 & 82 & 82 & 82 \\
\cline { 2 - 6 } & $\begin{array}{c}\text { Std. } \\
\text { Deviati } \\
\text { on }\end{array}$ & .61603 & .44410 & .38826 & .42220 \\
\hline \multirow{4}{*}{$\begin{array}{c}\text { Fema } \\
\text { le }\end{array}$} & Mean & 4.1483 & 3.7222 & 3.8783 & 3.8636 \\
\cline { 2 - 6 } & N & 84 & 84 & 84 & 84 \\
\cline { 2 - 6 } & $\begin{array}{c}\text { Std. } \\
\text { Deviati } \\
\text { on }\end{array}$ & .45548 & .63447 & .64110 & .43700 \\
\hline
\end{tabular}

Findings from the study indicated slight differences in the EI of both gender that participated in the survey. Female participants recorded high scores of all the four measures of emotional intelligence.

Concerning the construct of self-awareness the female scored a mean of (Mean $=4.15$, ) compared to the men who scored mean $=4.12$. This is an indication that women were more aware of their feelings and emotions and they recognize these feelings hence know what to say concerning presence, sense of humour, goals, values, strengths and weaknesses.

On the issue of emotional regulation, the female participants scored higher (Mean $=3.72$ ), compared to their male counterparts who scored mean $=3.63$. This is an implication that women could predict their feelings better than men and were able to deal better with stress, disappointment, pressures, negativity, and generally control their emotions using whatever means.

Self-motivation was also higher in the female participant $($ Mean $=3.88)$ than in male participants $($ Mean $=$ 3.82). Women seemed to be more result oriented and continuously worked to improve performance. Before beginning a task, women generally would anticipate success. They were more likely therefore to continue even when situations became difficult to handle.

The female participants also scored higher means in social skills $($ Mean $=3.86)$ compared to men $($ Mean= 3.80). Women promoted communication better, they were more polite and encouraged open discussions and debate. They looked forward to relationships that are mutually useful and tried to work in teams. They were generally friendly and cooperative. They could easily relate with strangers. The overall high scores for women therefore depicted higher levels of emotional intelligence in women than in men. To further analyze the differences in these means, the researcher did an independent t-test and results are presented in table 4

Table 4: A t-Test of Variance of Emotional Intelligence by Gender

\begin{tabular}{|c|c|c|c|c|c|c|}
\hline & & $\mathrm{t}$ & df & $\begin{array}{l}\text { Sig. } \\
(2- \\
\text { taile } \\
\text { d) }\end{array}$ & $\begin{array}{l}\text { Mean } \\
\text { Diffe } \\
\text { rence }\end{array}$ & $\begin{array}{c}\text { Std. } \\
\text { Erro } \\
r \\
\text { Diff } \\
\text { eren } \\
\text { ce }\end{array}$ \\
\hline \multirow{2}{*}{$\begin{array}{c}\text { Emotion } \\
\text { al } \\
\text { Intellige } \\
\text { nce (Self } \\
\text { Awarene } \\
\text { ss) }\end{array}$} & $\begin{array}{c}\text { Equal } \\
\text { variances } \\
\text { assumed }\end{array}$ & -.353 & 164 & .724 & $\begin{array}{c}- \\
.0296 \\
4\end{array}$ & $\begin{array}{c}.083 \\
95\end{array}$ \\
\hline & $\begin{array}{c}\text { Equal } \\
\text { variances } \\
\text { not } \\
\text { assumed }\end{array}$ & -.352 & $\begin{array}{c}149.08 \\
7\end{array}$ & .725 & $\begin{array}{c}- \\
.0296 \\
4\end{array}$ & $\begin{array}{c}.084 \\
25\end{array}$ \\
\hline \multirow{2}{*}{$\begin{array}{c}\text { Emotion } \\
\text { al } \\
\text { Intellige } \\
\text { nce } \\
\text { (Emotio } \\
\text { nal } \\
\text { Regulati } \\
\text { on) }\end{array}$} & $\begin{array}{c}\text { Equal } \\
\text { variances } \\
\text { assumed }\end{array}$ & $\begin{array}{c}- \\
1.03 \\
4 \\
\end{array}$ & 164 & .303 & $\begin{array}{c}- \\
.0880 \\
8 \\
\end{array}$ & $\begin{array}{c}.085 \\
19\end{array}$ \\
\hline & $\begin{array}{c}\text { Equal } \\
\text { variances } \\
\text { not } \\
\text { assumed }\end{array}$ & $\begin{array}{c}- \\
1.03 \\
8\end{array}$ & $\begin{array}{c}148.81 \\
1\end{array}$ & .301 & $\begin{array}{c}- \\
.0880 \\
8\end{array}$ & $\begin{array}{c}.084 \\
84\end{array}$ \\
\hline $\begin{array}{c}\text { Emotion } \\
\text { al } \\
\text { Intellige }\end{array}$ & $\begin{array}{c}\text { Equal } \\
\text { variances } \\
\text { assumed }\end{array}$ & -.726 & 164 & .469 & $\begin{array}{c}- \\
.0598 \\
8\end{array}$ & $\begin{array}{c}.082 \\
51\end{array}$ \\
\hline
\end{tabular}




\begin{tabular}{|c|c|c|c|c|c|c|}
\hline $\begin{array}{c}\text { nce } \\
\text { (Self- } \\
\text { Motivati } \\
\text { on) } \\
\end{array}$ & $\begin{array}{c}\text { Equal } \\
\text { variances } \\
\text { not } \\
\text { assumed } \\
\end{array}$ & -.730 & $\begin{array}{c}137.23 \\
3\end{array}$ & .467 & $\begin{array}{c}- \\
.0598 \\
8\end{array}$ & $\begin{array}{c}.082 \\
04\end{array}$ \\
\hline \multirow{2}{*}{$\begin{array}{c}\text { Emotion } \\
\text { al } \\
\text { Intellige } \\
\text { nce } \\
\text { (Social } \\
\text { Skills) }\end{array}$} & $\begin{array}{c}\text { Equal } \\
\text { variances } \\
\text { assumed }\end{array}$ & $\begin{array}{c}1.03 \\
4 \\
\end{array}$ & 164 & .303 & $\begin{array}{c}.0689 \\
9 \\
\end{array}$ & $\begin{array}{c}.066 \\
72\end{array}$ \\
\hline & $\begin{array}{c}\text { Equal } \\
\text { variances } \\
\text { not } \\
\text { assumed }\end{array}$ & $\begin{array}{c}- \\
1.03 \\
5\end{array}$ & $\begin{array}{c}163.98 \\
3\end{array}$ & .302 & $\begin{array}{c}- \\
.0689 \\
9\end{array}$ & $\begin{array}{c}.066 \\
69\end{array}$ \\
\hline
\end{tabular}

The findings indicted that there were no significant differences in emotional intelligence of the academic staff in term of gender. Both genders revealed no significant differences in all the EI constructs. Self - awareness $(\mathrm{t}(164)=$ -0.353, $\mathrm{p}>0.05)$, Emotional regulation, $(\mathrm{t}(164)=-1.034, \mathrm{p}$ $>0.05)$, Self- motivation, $(\mathrm{t}(164)=-0.726, \mathrm{p}>0.05)$ and Social skills $(\mathrm{t}(164)=-1.034, \mathrm{p}>0.05)$.

\section{The Role of Education levels in Emotional intelligence}

The study sought to examine the way in which emotional intelligence varied across the education levels of the participants. Results are presented in table 5. Moreover, trends that were evident in the change of EI with level of education are presented in Figure 2.

\begin{tabular}{|c|c|c|c|c|c|}
\hline \multicolumn{2}{|c|}{$\begin{array}{l}\text { Highest Level of } \\
\text { Education }\end{array}$} & $\begin{array}{l}\text { Emotion } \\
\text { al } \\
\text { Intellige } \\
\text { nce (Self } \\
\text { Awaren } \\
\text { ess) }\end{array}$ & $\begin{array}{l}\text { Emotion } \\
\text { al } \\
\text { Intellige } \\
\text { nce } \\
\text { (Emotio } \\
\text { nal } \\
\text { Regulati } \\
\text { on) } \\
\end{array}$ & $\begin{array}{l}\text { Emotion } \\
\text { al } \\
\text { Intellige } \\
\text { nce } \\
\text { (Self- } \\
\text { Motivati } \\
\text { on) }\end{array}$ & $\begin{array}{c}\text { Emotion } \\
\text { al } \\
\text { Intellige } \\
\text { nce } \\
\text { (Social } \\
\text { Skills) }\end{array}$ \\
\hline \multirow{3}{*}{$\begin{array}{l}\text { Gradu } \\
\text { ate }\end{array}$} & Mean & 4.0255 & 3.5600 & 3.8711 & 3.7846 \\
\hline & $\mathrm{N}$ & 25 & 25 & 25 & 25 \\
\hline & $\begin{array}{c}\text { Std. } \\
\text { Deviati } \\
\text { on }\end{array}$ & .39147 & .47219. & .31863 & .41126 \\
\hline \multirow{3}{*}{$\begin{array}{l}\text { Maste } \\
\text { r's } \\
\text { Degre } \\
\text { e }\end{array}$} & Mean & 4.2026 & 3.7225 & 3.8502 & 3.8796 \\
\hline & $\mathrm{N}$ & 92 & 92 & 92 & 92 \\
\hline & $\begin{array}{c}\text { Std. } \\
\text { Deviati } \\
\text { on } \\
\end{array}$ & .63674 & .58715 & .39788 & .40916. \\
\hline \multirow[b]{3}{*}{$\mathrm{PhD}$} & Mean & 4.0269 & 3.6500 & 3.8611 & 3.7587 \\
\hline & $\mathrm{N}$ & 44 & 44 & 44 & 44 \\
\hline & $\begin{array}{c}\text { Std. } \\
\text { Deviati } \\
\text { on }\end{array}$ & .36341 & .52081 & .80271 & .45481 \\
\hline \multirow{3}{*}{$\begin{array}{l}\text { Post- } \\
\text { Docto } \\
\text { ral }\end{array}$} & Mean & 4.3030 & 3.5556 & 3.2222 & 3.3590 \\
\hline & $\mathrm{N}$ & 3 & 3 & 3 & 3 \\
\hline & $\begin{array}{c}\text { Std. } \\
\text { Deviati } \\
\text { on }\end{array}$ & .18924 & .42861 & .33333 & .42366 \\
\hline \multirow[b]{3}{*}{ Other } & Mean & 4.4091 & 3.9667 & 4.1667 & 4.3462 \\
\hline & $\mathrm{N}$ & 2 & 2 & 2 & 2 \\
\hline & $\begin{array}{c}\text { Std. } \\
\text { Deviati } \\
\text { on }\end{array}$ & 44998 & .42426 & .54997 & .48954 \\
\hline
\end{tabular}

The results from the study indicate that graduates with a post- doctoral degree recorded high scores in self- awareness only (Mean $=4.30)$ where they came second after the academic staff with 'Other' qualification.( Mean= 4.41). This could be attributed to the fact that advancement in education gives more knowledge and therefore can lead to better understanding of self. This implied that they were aware of their feelings and emotions which helped them understand their sad and happy moments. However, in all the other constructs of emotional intelligence they scored low with emotional regulation (mean $=3.56$ ) self - motivation $($ Mean $=3.22)$ and social skills $($ mean $=3.36)$. Individuals at higher level of education tend to stand alone and differentiate themselves from group operations and probably the reason for reduction in social skills. Post-doctoral and the academic staff who recorded their qualification as others generally posted high means probably due to the sample where they had $\mathrm{N}=3$ and $\mathrm{N}=2$ respectively.

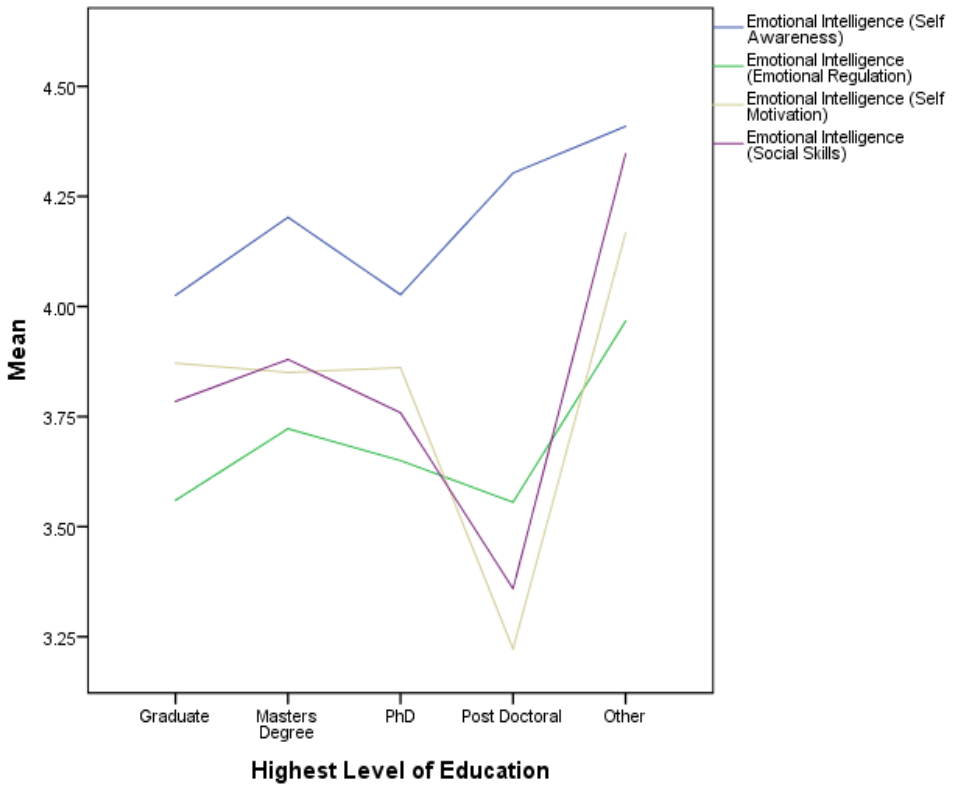

Figure 2

The findings demonstrated by figure 2 clearly indicate an up and down trend for most of the constructs. In self - awareness, graduates had a score of $($ Mean $=4.01)$ it however rose considerably at the masters' level to Mean= 4.20. However, at the $\mathrm{PhD}$ level, less self- awareness was experienced $($ Mean $=4.03)$. Academic staff concentrated more on other issues and were less self- aware. However, the staff became more aware at the post- doctoral level (Mean=4.30) and other $($ Mean=4.41).

Emotional regulation had a similar trend where graduates scored low $($ Mean= 3.56) and the masters scored higher (Mean = 3.72). However, the trend went down at the $\mathrm{PhD}$ level who had a mean of (Mean =3.65) and even lower at the post -doctoral level (Mean =3.56). The group that was labelled as other scored the highest (Mean $=3.97$ ) probably due to their low numbers since they were only 2 in number.

The self- motivation of the academic staff was also presented in figure 2 with the curve seemingly going down 
with the advancement in the education levels. Apart from the $\mathrm{PhD}$ levels that records slightly higher than the preceding academic level, a down ward trend was observed as less motivation was observed with increase in the level of education. The graduates recorded a mean of 3.87, Masters (Mean $=3.85$ ), Post-doctoral $($ Mean $=3.22$ ). However, the group labelled as others also recorded a high mean of 4.17 in terms of motivation. The trend implies that the more one accomplishes their academic dreams, they less they get motivated in doing other things since they get close to what they had aspired to get.

Social skills on the other hand increased for the first two levels of academics. The graduates with a mean of 3.78 increased to a mean of 3.88. For the other levels however, the trend went down as the social skills reduced with increased levels of academic education. Academic staff with $\mathrm{PhD}$ (Mean $=3.76$ ), and post-doctoral (Mean =3.36). The more one advanced in levels of education, the less social they tended to become since they differentiated themselves and worked better as a person than in teams.

To further assert on the significance of the differences in means discussed, the study did an analysis of variance for the four constructs of EI against the levels of education. Results of the analysis are presented in table 6

\begin{tabular}{|c|c|c|c|c|c|c|}
\hline \multicolumn{7}{|c|}{$\begin{array}{c}\text { Table 6: One-Way Analysis of Variance of Emotional Intelligence by Level } \\
\text { of Education }\end{array}$} \\
\hline & & $\begin{array}{c}\text { Sum } \\
\text { of } \\
\text { Square } \\
\text { s }\end{array}$ & df & $\begin{array}{l}\text { Mean } \\
\text { Squar } \\
\text { e }\end{array}$ & F & Sig \\
\hline \multirow{3}{*}{$\begin{array}{c}\text { Emotional } \\
\text { Intelligenc } \\
\mathrm{e} \\
\text { (Self- } \\
\text { Awareness } \\
\text { ) }\end{array}$} & $\begin{array}{c}\text { Betwee } \\
n \\
\text { Groups }\end{array}$ & 1.469 & 4 & .367 & $\begin{array}{c}1.27 \\
1\end{array}$ & .28 \\
\hline & $\begin{array}{l}\text { Within } \\
\text { Groups }\end{array}$ & 46.525 & $\begin{array}{c}16 \\
1\end{array}$ & .289 & & \\
\hline & Total & 47.995 & $\begin{array}{c}16 \\
5\end{array}$ & & & \\
\hline \multirow{3}{*}{$\begin{array}{c}\text { Emotional } \\
\text { Intelligenc } \\
\mathrm{e} \\
\text { (Emotiona } \\
1 \\
\text { Regulation } \\
\text { ) }\end{array}$} & $\begin{array}{c}\text { Betwee } \\
n \\
\text { Groups }\end{array}$ & .776 & 4 & .194 & .638 & $\begin{array}{c}.63 \\
6\end{array}$ \\
\hline & $\begin{array}{l}\text { Within } \\
\text { Groups }\end{array}$ & 48.933 & $\begin{array}{c}16 \\
1\end{array}$ & .304 & & \\
\hline & Total & 49.709 & $\begin{array}{c}16 \\
5\end{array}$ & & & \\
\hline \multirow{3}{*}{$\begin{array}{c}\text { Emotional } \\
\text { Intelligenc } \\
\mathrm{e} \\
\text { (Self- } \\
\text { Motivatio } \\
\mathrm{n} \text { ) }\end{array}$} & $\begin{array}{c}\text { Betwee } \\
n \\
\text { Groups }\end{array}$ & 1.399 & 4 & .350 & $\begin{array}{c}1.24 \\
9\end{array}$ & $\begin{array}{c}.29 \\
2\end{array}$ \\
\hline & $\begin{array}{l}\text { Within } \\
\text { Groups }\end{array}$ & 45.074 & $\begin{array}{c}16 \\
1\end{array}$ & .280 & & \\
\hline & Total & 46.473 & $\begin{array}{c}16 \\
5\end{array}$ & & & \\
\hline \multirow{3}{*}{$\begin{array}{c}\text { Emotional } \\
\text { Intelligenc } \\
\mathrm{e} \\
\text { (Social } \\
\text { Skills) }\end{array}$} & $\begin{array}{c}\text { Betwee } \\
n \\
\text { Groups }\end{array}$ & 1.700 & 4 & .425 & $\begin{array}{c}2.37 \\
6\end{array}$ & $\begin{array}{c}.05 \\
4\end{array}$ \\
\hline & $\begin{array}{l}\text { Within } \\
\text { Groups }\end{array}$ & 28.787 & $\begin{array}{c}16 \\
1\end{array}$ & .179 & & \\
\hline & Total & 30.486 & $\begin{array}{c}16 \\
5\end{array}$ & & & \\
\hline
\end{tabular}

The findings presented on the table indicate that there were no significant differences in the mean of selfawareness, $(\mathrm{F}(4,161)=1.271, \mathrm{p}>0.05)$ Emotional regulation, $(\mathrm{F}(4,161)=0.638, \mathrm{p}>0.05)$ and self- motivation $(\mathrm{F}(4,161)=1.292, \mathrm{p}>0.05)$. Moreover, the mean of social skills had a significant difference in terms of level of education $(\mathrm{F}(4,161)=2.376, \mathrm{p}=0.05)$

\section{The Role of Teaching Experience in Emotional intelligence}

The study sought to establish the differences in emotional intelligence variation across the years of teaching experience of the participants. The findings were reported in Table 7 where trends were further presented in Figure 3.

\begin{tabular}{|c|c|c|c|c|c|}
\hline \multicolumn{2}{|c|}{$\begin{array}{l}\text { Years of } \\
\text { Teaching in the } \\
\text { University }\end{array}$} & $\begin{array}{c}\text { Emotion } \\
\text { al } \\
\text { Intellige } \\
\text { nce (Self } \\
\text { Awarene } \\
\text { ss) }\end{array}$ & $\begin{array}{c}\text { Emotion } \\
\text { al } \\
\text { Intellige } \\
\text { nce } \\
\text { (Emotion } \\
\text { al } \\
\text { Regulati } \\
\text { on) } \\
\end{array}$ & $\begin{array}{l}\text { Emotion } \\
\quad \text { al } \\
\text { Intelligen } \\
\text { ce (Self- } \\
\text { Motivati } \\
\quad \text { on) }\end{array}$ & $\begin{array}{c}\text { Emotion } \\
\text { al } \\
\text { Intellige } \\
\text { nce } \\
\text { (Social } \\
\text { Skills) }\end{array}$ \\
\hline \multirow{3}{*}{$\begin{array}{l}0-5 \\
\text { yea } \\
\text { rs }\end{array}$} & Mean & 4.0897 & 3.6798 & 3.9211 & 3.8279 \\
\hline & $\mathrm{N}$ & 76 & 76 & 76 & 76 \\
\hline & $\begin{array}{l}\text { Std. } \\
\text { Deviati } \\
\text { on }\end{array}$ & .46910 & . 41740 & .63965 & .39541 \\
\hline \multirow{3}{*}{$\begin{array}{c}6- \\
10 \\
\text { yea } \\
\text { rs }\end{array}$} & Mean & 4.2869 & 3.8385 & 3.8716 & 3.9675 \\
\hline & $\mathrm{N}$ & 45 & 45 & 45 & 45 \\
\hline & $\begin{array}{c}\text { Std. } \\
\text { Deviati } \\
\text { on }\end{array}$ & .74839 & .78283 & .35923 & .47856 \\
\hline \multirow{3}{*}{$\begin{array}{c}11- \\
15 \\
\text { yea } \\
\text { rs }\end{array}$} & Mean & 4.0469 & 3.4882 & 3.6918 & 3.6973 \\
\hline & $\mathrm{N}$ & 31 & 31 & 31 & 31 \\
\hline & $\begin{array}{l}\text { Std. } \\
\text { Deviati } \\
\text { on }\end{array}$ & .33597 & .42562 & .46144 & .39769 \\
\hline \multirow{3}{*}{$\begin{array}{c}16- \\
20 \\
\text { yea } \\
\text { rs }\end{array}$} & Mean & 3.9273 & 3.4800 & 3.6556 & 3.5231 \\
\hline & $\mathrm{N}$ & 10 & 10 & 10 & 10 \\
\hline & $\begin{array}{c}\text { Std. } \\
\text { Deviati } \\
\text { on }\end{array}$ & .34763 & .32019 & .40386 & .36766 \\
\hline \multirow{4}{*}{$\begin{array}{c}21- \\
25 \\
\text { yea } \\
\text { rs }\end{array}$} & Mean & 4.4318 & 3.8333 & 3.9167 & 4.0962 \\
\hline & $\mathrm{N}$ & 4 & 4 & 4 & 4 \\
\hline & $\begin{array}{c}\text { Std. } \\
\text { Deviati } \\
\text { on }\end{array}$ & .22727 & .43033 & .47467 & .18176 \\
\hline & & & & & \\
\hline
\end{tabular}

The various factors of Emotional intelligence had variation with the teaching experience of the academic staff. Across all the four measures used to determine emotional intelligence, there was a high mean score for those who had taught for 21-25 years. Self-awareness (Mean $=4.43$ ), emotional regulation (Mean $=3.83$ ), self-motivation (Mean $=3.92)$ and social skills $($ Mean $=4.10)$. 


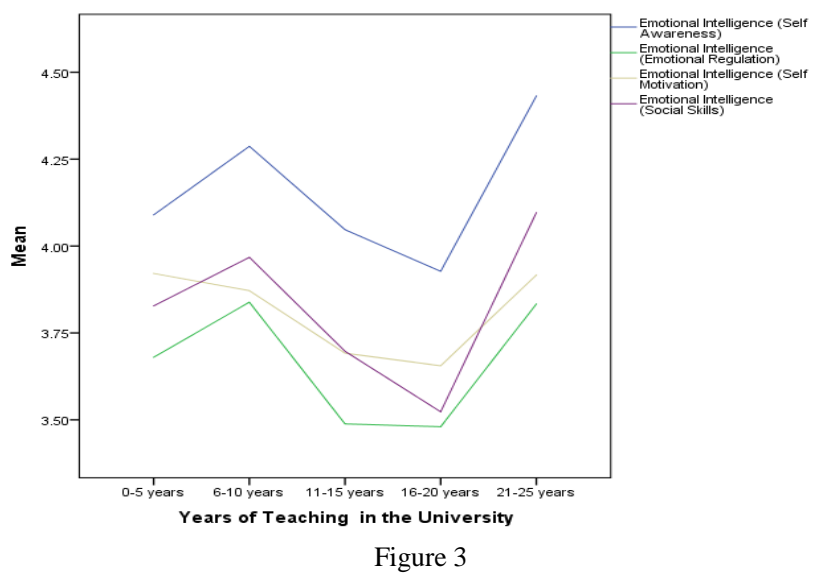

On self- awareness, those who had worked for less than 5 years scored low (Mean =4.09). Bearing in a new workstation, they had less self- awareness since they needed more time to know themselves. However, at the 6-10 years self- awareness increased (Mean $=4.29$ ). The trend of self awareness however started going down with the increase in teaching experience. $11-15$ years $($ Mean $=4.05), 16-20$ years (Mean $=3.93$ ). Familiarity with a teaching environment could reduce an individual's sensitivity to how their emotions affect them and affect others in the work place due to normalization of events and activities at the work place. This research was generally concerned about general experience in terms of length of time. However at the experience of 21-25 years the scores went up to Mean $=4.43$.

The emotional regulation increase with more experience at the beginning of working period. Workers who had 0-5 years had a mean of 3.68 while those with 6-10 years (Mean $=3.84)$. Workers who had just gotten employed seemed to regulate their emotions well. However, the ones who had worked for 11-15 years (Mean $=3.49$ ) and those who had worked for 16-20 years recorded diminishing scores. However, the emotional regulation rose at the ages of 21-25 (Mean =3.83)

The self- motivation of the workers recorded diminishing scores with increase in the years of experience. The scores reduced from 0-5 years $($ Mean $=3.92)$ to 6-10 years $($ Mean =3.87), 11-15 (Mean =3.69) and 16-20 years (Mean $=3.66)$. However the score for self- motivation increased at age 21-25 (Mean =3.92).

Social skills increased considerably during the first years of teaching where those who taught for 0-5 years scored Mean $=3.83$ while $6-10$ years scored Mean $=3.97$. The scores however started a downward trend towards 11-15 years of experience $(\mathrm{Mean}=3.70)$, to $16-20$ years experience (Mean $=3.52$ ).

The study further sought to determine the significance of the mean differences in the teaching experience. Results of analysis of variance are presented in table 8 .

\begin{tabular}{|c|c|c|c|c|c|c|}
\hline & & $\begin{array}{c}\text { Sum } \\
\text { of } \\
\text { Square } \\
\text { s } \\
\end{array}$ & $\mathrm{df}$ & $\begin{array}{c}\text { Mean } \\
\text { Squar } \\
\text { e }\end{array}$ & $\mathrm{F}$ & $\begin{array}{l}\text { Sig } \\
\text {. }\end{array}$ \\
\hline \multirow{3}{*}{$\begin{array}{c}\text { Emotional } \\
\text { Intelligenc } \\
\mathrm{e} \\
\text { (Self- } \\
\text { Awareness } \\
\text { ) }\end{array}$} & $\begin{array}{c}\text { Betwee } \\
n \\
\text { Groups }\end{array}$ & 2.218 & 4 & .554 & $\begin{array}{c}1.95 \\
0\end{array}$ & $\begin{array}{c}.10 \\
5\end{array}$ \\
\hline & $\begin{array}{l}\text { Within } \\
\text { Groups }\end{array}$ & 45.777 & $\begin{array}{c}16 \\
1 \\
\end{array}$ & .284 & & \\
\hline & Total & 47.995 & $\begin{array}{c}16 \\
5 \\
\end{array}$ & & & \\
\hline \multirow{3}{*}{$\begin{array}{c}\text { Emotional } \\
\text { Intelligenc } \\
\mathrm{e} \\
\text { (Emotiona } \\
1 \\
\text { Regulation } \\
\text { ) }\end{array}$} & $\begin{array}{c}\text { Betwee } \\
n \\
\text { Groups }\end{array}$ & 2.765 & 4 & .691 & $\begin{array}{c}2.37 \\
1\end{array}$ & $\begin{array}{c}.05 \\
5\end{array}$ \\
\hline & $\begin{array}{l}\text { Within } \\
\text { Groups }\end{array}$ & 46.944 & $\begin{array}{c}16 \\
1\end{array}$ & .292 & & \\
\hline & Total & 49.709 & $\begin{array}{c}16 \\
5 \\
\end{array}$ & & & \\
\hline \multirow{3}{*}{$\begin{array}{c}\text { Emotional } \\
\text { Intelligenc } \\
\mathrm{e} \\
\text { (Self- } \\
\text { Motivatio } \\
\mathrm{n} \text { ) }\end{array}$} & $\begin{array}{c}\text { Betwee } \\
n \\
\text { Groups }\end{array}$ & 1.577 & 4 & .394 & $\begin{array}{c}1.41 \\
3\end{array}$ & $\begin{array}{c}.23 \\
2\end{array}$ \\
\hline & $\begin{array}{l}\text { Within } \\
\text { Groups }\end{array}$ & 44.896 & $\begin{array}{c}16 \\
1 \\
\end{array}$ & .279 & & \\
\hline & Total & 46.473 & $\begin{array}{c}16 \\
5\end{array}$ & & & \\
\hline \multirow{3}{*}{$\begin{array}{c}\text { Emotional } \\
\text { Intelligenc } \\
\text { e (Social } \\
\text { Skills) }\end{array}$} & $\begin{array}{c}\text { Betwee } \\
n \\
\text { Groups }\end{array}$ & 2.623 & 4 & .656 & $\begin{array}{c}3.78 \\
9\end{array}$ & $\begin{array}{c}.00 \\
6\end{array}$ \\
\hline & $\begin{array}{l}\text { Within } \\
\text { Groups }\end{array}$ & 27.864 & $\begin{array}{c}16 \\
1 \\
\end{array}$ & .173 & & \\
\hline & Total & 30.486 & $\begin{array}{c}16 \\
5\end{array}$ & & & \\
\hline
\end{tabular}

The findings presented on the table indicated that there was no significant differences in the mean of selfawareness, $(\mathrm{F}(4,161)=1.950, \mathrm{p}>0.05)$ Emotional regulation, $(\mathrm{F}(4,161)=2.371, \mathrm{p}>0.05)$ and self- motivation $(\mathrm{F}(4,161)=1.413, \mathrm{p}>0.05)$. However, the mean of social skills had a significant difference in terms of experience that an academic staff possessed in teaching $(F(4,161)=3.789$, $p$ $<0.05)$

\section{The Role of Type of University in Emotional intelligence}

The study sought to establish the differences in the various measures of emotional intelligence variation across the two types of university where participants were drawn from. Results are indicated in table 9.

\begin{tabular}{|c|c|c|c|c|c|}
\hline \multicolumn{5}{|c|}{ Table 9: Difference in Emotional intelligence in terms of Type of university } \\
\hline \multicolumn{7}{|c|}{ Type of University } & $\begin{array}{c}\text { Emotion } \\
\text { al } \\
\text { Intellige } \\
\text { nce } \\
\text { (Self } \\
\text { Awaren } \\
\text { ess) }\end{array}$ & $\begin{array}{c}\text { Emotion } \\
\text { al } \\
\text { Intellige } \\
\text { nce } \\
\text { (Emotio } \\
\text { nal } \\
\text { Regulati } \\
\text { on) }\end{array}$ & $\begin{array}{c}\text { Emotion } \\
\text { al } \\
\text { Intellige } \\
\text { nce } \\
\text { (Self- } \\
\text { Motivati } \\
\text { on) }\end{array}$ & $\begin{array}{c}\text { Emotion } \\
\text { al } \\
\text { Intellige } \\
\text { nce } \\
\text { (Social } \\
\text { Skills) }\end{array}$ \\
\hline \multirow{3}{*}{$\begin{array}{c}\text { Private } \\
\text { univers } \\
\text { ity }\end{array}$} & Mean & 4.1689 & 3.7251 & 3.8977 & 3.8741 \\
\cline { 2 - 6 } & $\begin{array}{c}\text { Std. } \\
\text { Deviat } \\
\text { ion }\end{array}$ & 113 & 113 & 113 & 113 \\
\hline Public & Mean & 4.0583 & 3.5799 & 3.7442 & 3.7344 \\
\hline
\end{tabular}




\begin{tabular}{|c|c|c|c|c|c|}
\hline \multirow{4}{*}{$\begin{array}{c}\text { Univer } \\
\text { sity }\end{array}$} & $\mathrm{N}$ & 53 & 53 & 53 & 53 \\
\cline { 2 - 6 } & $\begin{array}{c}\text { Std. } \\
\text { Deviat } \\
\text { ion }\end{array}$ & .42307 & .53118 & .35977 & .48335 \\
\cline { 2 - 6 } & & & & & \\
\hline
\end{tabular}

The findings of the study gave a trend of a higher score in every measure of emotional intelligence for academic staff in private universities. The lecturers in private university $($ Mean $=4.17)$ were more self- aware and were more in touch with their feelings than those in public universities. (Mean = 4.06) similarly, they were more competent in regulating their emotions in private $($ Mean $=3.73$ ) than those in public university (Mean $=4.13$ ) this is a repeated pattern for, selfmotivation Private $($ Mean $=3.90)$ and Public $($ Mean $=3.74)$ and social skills, private $($ Mean $=3.87$ ) and public ( Mean =3.73). This is a clear indicator that besides being aware of their feelings and how their emotions affect their teaching, the lectures were also able to manage their feelings well amidst crisis. They showed higher levels of energy in terms of motivation to work. The socials skills in team work, communication and other social skills were more pronounced in academic staff of private than public university.

An independent $t$ - test was further run-in order to ascertain the significance of the mean differences in EI of the academic staff in terms of the type of university that they were teaching. The results are indicted in table 10.

Table 10: A t-Test of Career Adaptability by Type of University

\begin{tabular}{|c|c|c|c|c|c|c|}
\hline & & $\mathrm{t}$ & df & $\begin{array}{l}\text { Sig. } \\
\text { (2- } \\
\text { taile } \\
\text { d) }\end{array}$ & $\begin{array}{c}\text { Mean } \\
\text { Differe } \\
\text { nce }\end{array}$ & $\begin{array}{c}\text { Std. } \\
\text { Error } \\
\text { Differe } \\
\text { nce }\end{array}$ \\
\hline \multirow{2}{*}{$\begin{array}{c}\text { Emotion } \\
\text { al } \\
\text { Intellige } \\
\text { nce } \\
\text { (Self } \\
\text { Awaren } \\
\text { ess) }\end{array}$} & $\begin{array}{c}\text { Equal } \\
\text { varian } \\
\text { ces } \\
\text { assum } \\
\text { ed }\end{array}$ & $\begin{array}{l}1.2 \\
34\end{array}$ & 164 & 219 & .11063 & .08965 \\
\hline & $\begin{array}{c}\text { Equal } \\
\text { varian } \\
\text { ces } \\
\text { not } \\
\text { assum } \\
\text { ed }\end{array}$ & $\begin{array}{l}1.3 \\
83\end{array}$ & $\begin{array}{c}136.1 \\
02\end{array}$ & . 169 & .11063 & 07999 \\
\hline \multirow{2}{*}{$\begin{array}{l}\text { Emotion } \\
\text { al } \\
\text { Intellige } \\
\text { nce } \\
\text { (Emotio } \\
\text { nal } \\
\text { Regulati } \\
\text { on) }\end{array}$} & $\begin{array}{c}\text { Equal } \\
\text { varian } \\
\text { ces } \\
\text { assum } \\
\text { ed }\end{array}$ & $\begin{array}{l}1.5 \\
96\end{array}$ & 164 & .112 & .14520 & 09095 \\
\hline & $\begin{array}{c}\text { Equal } \\
\text { varian } \\
\text { ces } \\
\text { not } \\
\text { assum } \\
\text { ed }\end{array}$ & $\begin{array}{l}1.6 \\
20\end{array}$ & $\begin{array}{c}105.6 \\
70\end{array}$ & . 108 & .14520 & .08962 \\
\hline \multirow{2}{*}{$\begin{array}{l}\text { Emotion } \\
\text { al } \\
\text { Intellige } \\
\text { nce } \\
\text { (Self- } \\
\text { Motivati } \\
\text { on) }\end{array}$} & $\begin{array}{c}\text { Equal } \\
\text { varian } \\
\text { ces } \\
\text { assum } \\
\text { ed }\end{array}$ & $\begin{array}{l}1.7 \\
48\end{array}$ & 164 & .082 & .15350 & .08781 \\
\hline & $\begin{array}{c}\text { Equal } \\
\text { varian } \\
\text { ces } \\
\text { not } \\
\end{array}$ & $\begin{array}{l}2.0 \\
67\end{array}$ & $\begin{array}{c}152.8 \\
42\end{array}$ & .040 & .15350 & .07426 \\
\hline
\end{tabular}

\begin{tabular}{|c|c|c|c|c|c|c|}
\hline & $\begin{array}{c}\text { assum } \\
\text { ed }\end{array}$ & & & & & \\
\hline \multirow{2}{*}{$\begin{array}{c}\text { Emotion } \\
\text { al } \\
\text { Intellige } \\
\text { nce } \\
\text { (Social } \\
\text { Skills) }\end{array}$} & $\begin{array}{c}\text { Equal } \\
\text { varian } \\
\text { ces } \\
\text { assum } \\
\text { ed }\end{array}$ & $\begin{array}{l}1.9 \\
69\end{array}$ & 164 & .051 & .13967 & .07095 \\
\hline & $\begin{array}{c}\text { Equal } \\
\text { varian } \\
\text { ces } \\
\text { not } \\
\text { assum } \\
\text { ed }\end{array}$ & $\begin{array}{l}1.8 \\
34\end{array}$ & $\begin{array}{c}86.07 \\
5\end{array}$ & .070 & .13967 & .07617 \\
\hline
\end{tabular}

Findings revealed that there were no significant mean differences in three constructs of EI. These include; Self awareness $(\mathrm{t}(164)=1.234, \mathrm{p}>0.05)$, Emotional regulation, $(\mathrm{t}$ $(164)=1.596 ., \mathrm{p}>0.05)$, and Self-motivation $(\mathrm{t}(164)=1.748$, $\mathrm{p}>0.05)$. The only construct that indicated a significant mean difference in EI in terms of type of university was the social skills of the academic staff. $(\mathrm{t}(164)=0.834, \mathrm{p}=0.05)$.

\section{DISCUSSION}

\section{Age and Emotional Intelligence}

Emotional Intelligence is a skill that can be developed over a lifetime, that is as years grow or as people advance in age, their EI also grows and improves. It also good to note that this skill can develop fully or sometimes it may develop via some training, practice, and experience to understand the concept.

The findings of this study clearly indicated a change of the various constructs of emotional intelligence with age. The lowest scores were recorded at age 29-39 (Mean =4.08). Similarly at the age of 62-72 there were high levels of emotional regulation (Mean $=3.93$ ) and self -motivation (Mean= 3.89).Employees at this age bracket were in charge of their emotions and were motivated at work. Contrary to this study however, Cabello, Sorrel, Fernandez-Pinto and Etremera (2016) in their study found out that EI ability resembled an inverted $u$ curve with people at the middle age scored higher as compared to younger and older adults.

This study recorded the highest level of selfawareness at the age of 62-72 (Mean = 4.18) where individuals seemingly were concerned about their feelings and were aware of their strength, weaknesses, values, goals and decision making strategies. In a study carried out by Anitei (2008) in America on people aged between 22 years to 70 years using six seconds emotional intelligence assessment (SEI). The sample consisted of 405 participants. This study revealed that older people have higher EI than those of young age. According to Tsaousis \& Kazi, 2013), older adults have a greater level of EI. When people stay long on their jobs, they become mature that is developed by lifelong learning and accumulated knowledge (Kaufman, Johnson, \& Liu, 2008). In addition, as people continue to grow and advance in age, so do their EI. Due to the skills gained and knowledge older adults are exposed to more opportunities to practice their EI compared to the young people. Experience is the best teacher, 
older adults who have worked for long period of time can understand, control and live with their emotions freely (Blanchard-Fields, 2007. In addition Kaufman et al agrees to the fact that as individuals grow older over the years, they seem to understand their own and other people's emotions as well. Older adults have more opportunities than young adults to practice emotional intelligence throughout their lives. Consequently, older adults have better understanding of emotions (Blanchard-Fields, 2007) and use better emotional regulation strategies than younger adults. However, when it came to social skills the oldest recorded low competencies in social skills (Mean $=3.62$ ) while the youngest age group 1829 recorded highest scores $($ Mean= 3.87).

\section{Gender and Emotional Intelligence}

All human beings are deemed to be emotionally intelligent but studies have shown otherwise; Findings from the study suggested that female participants recorded high scores of all the four measures of emotional intelligence. Selfawareness the female scored a mean of $($ Mean $=4.15$, compared to the men who scored mean $=4.12$. Emotional regulation, the female participants scored higher (Mean = 3.72), compared to their male counterparts who scored mean $=3.63$. This is an implication that women can predict their feelings better than men and are able to deal better with stress, disappointment, pressures, negativity, and generally control their emotions using whatever means. Self-motivation was also higher in the female participant (Mean = 3.88) than in male participants (Mean $=3.82$ ). This was consistent with another study too that suggested that females possessed a higher degree of EI compared to the males ( Patel, 2017).

Cabello, Sorrel, Fernandez-Pinto and Etremera (2016) carried out a study in which they analysed the ability of EI on Spanish adults aged between 17-76 years. They made use of the Mayer-Salovey-Caruso Emotional Intelligence Test (MSCEIT), which measures ability EI according to the 4 branches of the Mayer and Salovey EI model. This study found out that gender affects EI together with all the scores on the EI branches. EI ability was greater in women compared to male.

Chandra, Gayatri, \& Devi, (2017) carried out a study in Tamil Nadu, India. This study revealed that among the medical graduates, female students presented a higher level of EI than males. A similar study was also carried out by Ranasinghe, Wathurapatha, Mathangasinghe, \& Ponnamperuma (2017) in Sri Lanka among medical undergraduate students and their study also revealed that the female students presented a higher mean on EI compared to their male counterparts who participated in the same study.

Compared to other types of intelligence, Pardeller, Frajo-Apor, Kemmler, \& Hofer (2017) conclude in their research that male score higher in fluid ability tests compared to women who score in emotional ability tests. Other researcher have studied other constructs beyond EI and Siegling, Furnham, \& Petrides, (2015) suggest that in the society, there are some characteristics that are gender oriented for instance, men are known to be very assertive and women are known to be empathetic

This study and other studies however have recorded no significant differences in EI in terms of gender. According to Myint \& Aung (2016) in a study that was carried out in Myanmar, the findings rather depicted that there was no significant difference that existed between the EI of male and female teachers. A closely related study, investigating gender differences in EI and leadership effectiveness, found EI to be positively and significantly related to organizational leadership for both genders. Results however revealed no significant differences between male and female software professionals in terms of EI and overall leadership effectiveness (Singh, 2007)

\section{Teaching Experience and Emotional Intelligence}

The various factors of Emotional intelligence had variation with the teaching experience of the academic staff. Across all the four measures used to determine emotional intelligence, there was a high mean score for those who had taught for 21-25 years. Self-awareness (Mean = 4.43), emotional regulation (Mean $=3.83$ ), self-motivation (Mean $=3.92$ ) and social skills $($ Mean $=4.10)$.

Contrary to this findings, a research by Tseng, Yi and Yeh (2019) reported on the specialty of the experience where they noted that students with managerial experiences demonstrated a higher level of soft skills. For this study therefore the difference ws in the type of experience and not years. EI is aided by quite a number of factors. Golleman comments concerning experience

'Our level of emotional intelligence is not fixed genetically, nor does it develop only in early childhood. Unlike IQ, which changes little after our teen years, emotional intelligence seems to be largely learned, and it continues to develop as we go through life and learn from our experiences - our competence in it can keep growing. In fact, studies that have tracked people's level of emotional intelligence through the years show that people get better and better in these capabilities as they grow more adept at handling their emotions and impulses, at motivating themselves, and at honing their empathy and social adroitness. There is an old fashion word for this growth in emotional intelligence: maturity (Golleman, 1998, p. 7).'

Agreeing with what Golleman says with regard to EI and years of working experience, Bar-on (2006) asserts that, as one grows and matures, he/she then becomes more socially and emotionally intelligent. Intuitively, one might assume that emotional intelligence will increase as work experience increases meaning, the more the work of experience the more EI level. This is clearly evident in the last years of experience in the current research. 
Caruso, and Salovey (1999) asserted that in order for emotional intelligence to be considered a standard intelligence, it should increase with age and experience. The authors compared adolescents' and adults' performance on the Multifactor Emotional Intelligence Scale. Results showed that the adult group functioned at a significantly higher level of emotional intelligence than the adolescent group. In this section therefore there seems to be an agreement amongst many researchers with regard to the relationship between working experience and EI, it is assumed that the more the years of experience, the higher the level of EI. However that is not always the trend.

Scholars like Ngah, Jussof and Rahman (2009) carried out a study on length of service and EI on the academic employees in Malaysia. This study found out that there was no significant relationship between working experience and the level of EI. Similarly, Landa, LopezZafra, Martos and Aquilar-Luzon (2008) also agrees that there is no significant clear relationship between a person's working experience and EI. They arrived at this after carrying out a study on the nurses in General hospitals in Spain. Generally the study has a varying trend where EI interchangeably goes high and low with experience especially at the formative years.

\section{Educational Level and Emotional Intelligence}

The inverse relationship between EI and career Adaptability that is evident in this research contradicts the findings of Tseng, Yi and Yeh (2019) who carried out a research in china on Learning-related soft skills among online business students in higher education. The results of their study indicated that graduate students had higher level of soft skills than undergraduate students, especially in selfregulation and motivation. This level of education however concerned students and therefore the difference in the settings where one was a learning situation and the current study measures EI against adaptability which is a job factor.

Contrary to the findings in this research, another researcher found out that educational level also has an impact on an individual's EI. According to Navarro-Bravo et al. (2019) higher education levels are always associated with better test performances.

\section{Type of University and Emotional Intelligence}

The findings of the study gave a trend of a higher score in every measure of emotional intelligence for academic staff in private universities. This findings are contrary with the findings of Sani, Masrek and Nadzar (2013) who in their study on the emotional intelligence profile of public librarians in Malaysia found out that public librarians have a good potential of competencies for self-awareness, selfmanagement, social awareness and relationship management. However, it was noted in their study that the highest competency possessed by Malaysian public librarians is the dimension of self-awareness; asserting that there is no doubt that working in public libraries requires high self-awareness because of the diversity of requests from various groups. However there were significant differences in social skills in terms of types of university.

\section{CONCLUSION}

It is key therefore for every university to consider the age, gender, level of education, and experience, of employees during recruitment and in assigning various tasks since it is notable that EI changes with these factors. Similarly there are variations of levels of self- awareness, emotional regulation, self-motivation and social skill in these predictors. In assigning tasks therefore, other tasks might require one construct of EI than another task.

An employee must be aware of their emotions and be able to regulate those emotions. When a person has good regulation of emotions, they are likely to be more satisfied at their work place. (Sandhu \& Ramesh, 2015). This also agrees with Chaturvedi \& Mishra (2017) who opine that when one is able to regulate their emotions well, there is likelihood that in the long run they will be more satisfied with their career. When looking at emotional conditions, job satisfaction is one of the condition that can be looked at says that this emotional condition can either be pleasant and unpleasant depending based on the ways the staff views their job (Arianto \& Choliq, 2019). Similarly issues of motivation and social skills of a person must be considered in line with the kind of task they are assigned.

\section{REFERENCES}

[1] Augusto L., J. M., López-Zafra, E., Berrios Martos, M. P., \& Aguilar Luzón, M. C. (2008). The relationship between emotional intelligence, occupational stress and health in nurses: A questionnaire survey. International Journal of Nursing Studies, 45, 88-901

[2] Blanchard-Fields, F., Chen, Y., Norris, L. (1997) Everyday problem solving across the adult life span: Influence of domain specificity and cognitive appraisal. Psychology and Aging 12(4): 684-693. doi:10.1037/0882-7974.12.4.684.

[3] Al-Hamami, N. M., Hashim, M. T., Songip, A. R., \& Al-Saeed, A. H. (2015). The effects of emotional intelligence on job satisfaction. Information and Knowledge Management, 5(6), 98101.

[4] Cabello, R., Sorrel, M.A., Fernandez- Pinto, I., Extremera, N., Fernández-Berrocal, P., (2016). Age and Gender Differences in Ability Emotional Intelligence in Adults: A cross-sectional study. Dev. Psychol. 52, 1486-1492.

[5] Chandra, A., Gayatri, A., Devi, D. (2017). Assessment of emotional intelligence in first year medical graduates-A Questionnaire based study. International Journal of Physiology, 5, 124-126. doi:10.5958/2320-608X.2017.00027.0

[6] Eymur G. \& O. Geban (2011). An investigation of the Relationship between Motivation and Academic Achievement of Pre- service Chemistry Teachers. Education and Science, 36, (161) 246-255, 2011.

[7] Feldman, G., Dunn, E., Stemke, C., Bell, K., \& Greeson, J. (2014). Mindfulness and rumination as predictors of persistence with a distress tolerance task. Personality and Individual Differences, 56, 154-158. doi:10.1016/j.paid.2013.08.040

[8] Frajo-Apor, B., Kemmler, G., Pardeller, S., Plass, T., Muehlbacher, M., Welte, A.S., \& Hofer, A. (2017). Emotional intelligence and non-social cognition in schizophrenia and bipolarI-disorder. Psychological Medicine, 47, 35-42.

[9] Goleman, D. (1995). Emotional intelligence. New York: Bantam. 
[10] Goleman, D. (1998). Working with emotional intelligence. New York: Bantam.

[11] Goleman, D. (2006). Social Intelligence: The New Science of Human Relationships. New York: Bntum Books.

[12] Gross, J. J., and Jazaieri, H. (2014). Emotion, emotion regulation, and psychopathology: an affective science perspective. Clin. Psychol. Sci. 2, 387-401. doi: 10.1177/2167702614536164.

[13] Gu, J., Strauss, C., Bond, R., \& Cavanagh, K. (2015). How do mindfulness-based cognitive therapy and mindfulness-based stress reduction improve mental health and wellbeing? A systematic review and meta-analysis of mediation studies. Clinical Psychology Review, 37, 1-12. doi:10.1016/j.cpr.2015.01.006

[14] Kamau, J. N., Githi, S. K. \& Njau, M. M. (2014). Research methods: Design of a Research Project. Nairobi: Multi-face Solution.

[15] Kumar D., Devi S., (2016). Emotional intelligence and social skills in relation to occupational self-efficacy of secondary school teachers. International Journal of Information Movement 1(4) 85103.

[16] Kaufman, A.S., \& Lichtenberger, E.O. (2006). Assessing adolescent and adult intelligence (3rd ed.). New York: Wiley.

[17] Maassen,P., Andreadakis,Z,. Gulbrandsen, M \& Stensaker,B. (2019).The Place of Universities in Society .University of Oslo.

[18] Masrek, M.N., Sahid, N. Z., \& Mohd N. F.,\& Abdullah S. J., (2013). Assessing the Emotional Intelligence Profile of Public Librarians in Malaysia: Descriptive Analysis. Library Philosophy and Practice (e-journal). 1047.

[19] Mayer, J. and Salovey, P. (1997) 'What is emotional intelligence?', in Salovey, P. and Sluyter, (Eds.): Emotional Development and Emotional Intelligence, Basic Books, New York, pp.3-31

[20] Mehta, S. Singh, N. (2013). Development of the Emotional Intelligence Scale. International journal of management and information technology.8 (1),1252-1264.

[21] Mugenda, A.G. (2009). Social science research. Nairobi: Acts Press.
[22] Nassaji H., (2015) Qualitative and descriptive research: Data type versus data analysis. Language Teaching Research, 19(2) $129-$ 132.

[23] Naz, S., Shah, S. A., \& Qayum, A. (2020). Gender differences in motivation and academic achievement: A study of the university students of KP, Pakistan. Global Regional Review, 5(I), 67-75.

[24] Ngah, R., Jussof, K., \& Rahman, Z. A. (2009). Emotional Intelligence of Malaysian Academics towards Work Performance. International Education Studies, 2(2), 103-112.

[25] Noorbakhsh, S. N., Besharata, M. A., and Zarei, J. (2012). Emotional intelligence and coping styles with stress. Proc. Soc. Behav. Sci. 5, 818-822. doi: 10.1016/j.sbspro.2010.07.191.

[26] Orodho, J. A. (2009). Elements of Education and Social Science Research Methods. (2 ${ }^{\text {nd }}$ Ed.).

[27] Pena-Sarrionandia, A., Mikolajczak M., \& Gross J., (2015). Integrating emotion regulation and emotional intelligence traditions: a meta-analysis. Frontiers in Psychology, 6(160), 1-26

[28] Sani M. K., Masrek M. N, Sahid N. Z., et al. (2013) Assessing the Emotional Intelligence Profile of Public Librarians in Malaysia: Descriptive Analysis. Available at: http:// digital commons. unl. edu/ libphilprac/1047/ (accessed 21 Juy, 2021.

[29] Sigh, S. (2007). Emotional intelligence and organisational leadership: a gender study in Indian context. International Journal of Indian Culture and Business Management 1(1/2) DOI:10.1504/IJICBM.2007.014470.

[30] Tsaousis, I., Kazi, S. (2013) Factorial invariance and latent mean differences of scores on trait emotional intelligence across gender and age. Personality and Individual Differences 54(2): 169-173. doi:10.1016/j.paid.2012.08.016.

[31] Tseng, H., Yi, X., \& Yeh, H.-T. (2019). Learning-related soft skills among online business students in higher education: Grade level and managerial role differences in self regulation, motivation, and social skill. Computers in Human Behavior, 95, 179-186

[32] Yamane, T., (1967) Statistics, An Introductory Analysis, $2^{\text {nd }}$ Ed., New York: Harper and Raw. 